\section{FAKTOR PREDIKTOR KELULUSAN UJIAN KOMPETENSI NERS INDONESIA : TINJAUAN LITERATUR}

\section{Predictors of Ners Indonesia Competency Exam Graduation: Literature Review}

\section{Basso Palingrungi, Kusrini S. Kadar, Elly Lilianty Sjattar}

Program Studi Magister Ilmu Keperawatan Fakultas Keperawatan, Universitas Hasanuddin

\section{Riwayat artikel}

Diajukan: 10 Februari 2021

Diterima: 22 Maret 2021

\section{Penulis Korespondensi: \\ - Basso Palingrungi \\ - Universitas Hasanuddin Indonesia}

\section{e-mail:}

baso.palingrungi@gmail.co $\underline{\mathrm{m}}$

\section{Kata Kunci: \\ Prediktor Ujian \\ Kompetensi, Uji \\ Kompetensi Ners}

\begin{abstract}
Abstrak
Pendahuluan: Kelulusan mahasiswa keperawatan dalam mengikuti UKNI sejak periode ke-IV terus menerus menurun dan sangat rendah jika dibandingkan dengan beberapa negara yang tingkat kelulusannya diatas $80 \%$. Tujuan studi ini yaitu untuk melihat prediktor terhadap tingkat kelulusan uji kompetensi nasional yang dapat diajukan sebagai salah satu upaya perbaikan institusi pendidikan. Metode Studi ini menggunakan desain literature review. Database yang digunakan yaitu PubMed, ClinicalKey Nursing, Google Scholar bahasa Inggris. Kata kunci sebagai berikut: nursing program "OR" nursing student "OR" undergraduate nursing program "AND" predictor NCLEX-RN "AND" NCLEX-RN Success. Pada database Google Scholar bahasa Indonesia, Portal Garuda dan pencarian sekunder menggunakan bahasa Indonesia dengan kata kunci program keperawatan "OR" mahasiswa perawat "OR" ners prekdiksi ujian kompetensi "OR" faktor yang mempengaruhi "DAN" Sukses Ukom. Kriteria inklusi yaitu (1) fokus pada prediktor ujian kompetensi, (2) diterapkan pada mahasiswa keperawatan, dan (3) dipublikasikan 10 tahun terakhir yaitu rentang tahun 2011-2020. Adapun kriteria eksklusi yaitu artikel yang tidak tersedia dalam teks lengkap, artikel berganda dan artikel yang tidak cocok dengan pertanyaan penelitian. Hasil: tinjauan literatur ini didapatkan 9 artikel yang sesuai dengan kriteria inklusi. Ada beberapa prediktor yang mempengaruhi keberhasilan dalam menghadapi ujian kompetensi diantaranya: prestasi akademik, hasil try out,bimbingan insentif, status akreditasi, Indepent test taker berbasis web e-learning dan faktor demografi..
\end{abstract}

\section{Abstract}

Introduction: Nursing student graduation from participating in UKNI since the fourth period has continued to decline and is very low when compared to some countries whose graduation rates are above $80 \%$. The purpose of this study is to see predictors of the passing rate of the national competency test that can be proposed as an effort to improve educational institutions. Method: This study uses a literature review design. The database used is PubMed, ClinicalKey Nursing, Google Scholar English. Keywords as follows: nursing program "OR" nursing student "OR" undergraduate nursing program "AND" predictor NCLEX-RN "AND" NCLEX-RN Success. In the Google Scholar database in Indonesian, Garuda Portal and secondary searches using Indonesian with the keyword nursing program "OR" nursing students "OR" ners competency exam prediction "OR" factors that affect "AND" Ukom success. The inclusion criteria were (1) focused on predictors of competency examinations, (2) applied to nursing students, and (3) published in the last 10 years, namely 2011-2020. The exclusion criteria were articles that were not available in the full text, multiple articles and articles that did not match the research question. Result: This literatur rewiew found 9 articles that match the inclusion criteria. There are several predictors that influence success in facing competency exams including: academic achievement, try out result, incentive guidance, accreditation status, independent e-learning web based test taker and factors demographic. 


\section{PENDAHULUAN}

Uji kompetensi adalah proses pengukuran pengetahuan, keterampilan, dan perilaku peserta didik pada perguruan tinggi yang menyelenggarakan program studi Keperawatan (Republik Indonesia, 2014). Tujuan dilakukannya uji kompetensi khususnya terhadap perawat lulusan baru adalah untuk melindungi masyarakat dengan memberikan jaminan bahwa perawat pada entry level registered memiliki kompetensi yang dipersyaratkan untuk dapat menjalankan praktek profesi secara aman dan efektif (Kariasa et al., 2018).

Lisensi telah lebih dulu dilaksanakan di luar negeri. Pada tahun 1938, New York merupakan Negara pertama yang mengundang-undangkan lisensi keperawatan. Uji kompetensi dilaksanakan tahun 1994 dengan nama National Council Licensing Examination for Registered Nurses (NCLEX-RN) yang dikenal sampai sekarang. uji lisensi tersebut dikelola oleh National Council of State Boards of Nursing (Benefiel, 2011).

Di Indonesia kebijakan pelaksanaan uji kompetensi dimulai secara bertahap sejak peraturan menteri kesehatan nomor 1796 tahun 2011 diterbitkan. Dalam permenkes tersebut dijelaskan bahawa seluruh tenaga kesehatan termasuk didalamnya perawat harus mengikuti uji kompetensi sebagai syarat memperoleh Surat Tanda Registrasi (STR) kebijakan ini diperkuat dengan diterbitkannya Undang-Undang No.38 tahun 2014 tentang Keperawatan. Sejak saat itu persiapan mulai dilakukan dan akhirnya pelaksanaan uji kompetensi mulai dilaksanakan pada 1 Agustus 2013 (RistekDikti, 2014).

Pelaksanaan Uji kompetensi Ners di Indonesia telah dilaksanakan sebanyak enam belas kali. Hasil UKNI dari tahun ke tahun mengalami tingkat kelulusan yang fluktuatif, data nasional Direktorat Penjaminan Mutu 3 tahun terakhir yaitu pada tahun 2017, peserta yang mengikuti UKNI yang dinyatakan kompeten/lulus berjumlah $20.754 \quad(51,15 \%)$ dan yang dinyatakan tidak kompeten/lulus berjumlah 19.822 (48,85\%), pada tahun 2018 peserta yang dinyatakan kompeten/lulus berjumlah $26.208(54,89 \%)$ dan yang dinyatakan tidak kompeten / lulus berjumlah 21.535 (45,11\%), pada tahun 2019 peserta yang dinyatakan kompeten/lulus berjumlah $29.240(55,16 \%)$ dan yang dinyatakan tidak kompeten/lulus berjumlah 21.535 (44,84\%) (Ristek Dikti, 2020). Mahasiswa peserta UKNI yang tidak lulus perlu mendapatkan perhatian, karena apabila tidak direspon dengan cepat dan tepat maka akan berdampak terhadap kualitas lulusan yang dinilai tidak kompeten sebagai Ners, mutu dari perguruan tinggi akan diragukan oleh masyarakat serta banyaknya dampak negatif terhadap mahasiswa Ners yang tidak lulus uji kompetensi (Kholifah et al., 2016). Ketidaklulusan mahasiswa keperawatan pada UKNI juga dapat menyebabkan mahasiswa tidak bisa memiliki Surat Tanda Registrasi (STR), sehingga bisa menyulitkan lulusan untuk mendapatkan pekerjaan di pelayanan kesehatan dan melalui STR tersebut perawat dapat melakukan pratik mandiri sebagai tanda pengakuan terhadap kompetensi perawat yang telah lulus Uji Kompetensi

Hasil Penelitian di Indonesia ada beberapa faktor-faktor yang mempengaruhi tingkat kelulusan mahasiswa dalam UKNI diantara yaitu persiapan, pelaksanaan (Kholifah et al., 2016), status akreditasi sebuah institusi berhubungan dengan tingkat kelulusan UKNI mahasiswanya (Masfuri, 2017). Sarana prasarana akademik berpengaruh terhadap kelulusan mahasiswa dalam UKNI (Syah et al., 2017).

Fenomena kelulusan mahasiswa keperawatan dalam mengikuti UKNI sejak periode ke-IV terus menerus menurun dan sangat rendah jika dibandingkan dengan beberapa negara yang tingkat kelulusannya diatas $80 \%$. Di Indonesia setiap institusi pendidikan menjalankan proses pendidikan dan pembelajaran mengacu pada standar yang sama yang telah ditetapkan oleh pemerintah, namun tingkat kelulusan mahasiswa dalam UKNI pada setiap institusi memiliki perbedaan yang sangat jauh signifikan. Rendahnya persentase kelulusan mahasiswa pada ujian kompetensi yang diadakan oleh 
Kemenristekdikti melalui Panitia Ujian Kompetesi Tenaga Kesehatan (PUKNakes) selayaknya menjadi bahan evaluasi. Adapun tujuan literature review ini adalah untuk melihat prediktor terhadap tingkat kelulusan uji kompetensi nasional yang dapat diajukan sebagai salah satu upaya perbaikan institusi pendidikan.

\section{METODE}

\section{Desain}

Penelitian ini menggunakan desain literature review. Strategi Pencarian literature pada artikel ini menggunakan Database PubMed, ClinicalKey Nursing, Google Scholar Bahasa Inggris. Kata kunci didasarkan pada database dalam istilah Title/Abstrak, penelitian pertanyaan disusun memakai elemen PICO (population, intervention, comparison and Outcome) dengan menggunakan bahasa inggris sebagai berikut : nursing program

(Title/Abstract) "OR" nursing student (Title/Abstract) "OR" undergraduate nursing program (Title/Abstract) "AND" predictor NCLEX-RN (Title/Abstract)

"AND" NCLEX-RN Success

(Title/Abstract) . Pada Database Google Scholar Bahasa Indonesia, Portal Garuda dan pencarian sekunder menggunakan Bahasa Indonesia dengan kata kunci Program keperawatan (Title/Abstract) "OR" mahasiswa Perawat (Title/Abstract) "OR" Ners (Title/Abstract) Prekdiksi Ujian Kompetensi (Title/Abstract) "OR" faktor yang mempengaruhi (Title/Abstract) "DAN" Sukses Ukom (Title/Abstract). Kriteria inklusi pada artikel review ini adalah (1) fokus pada prediktor ujian kompetensi, (2) diterapkan pada mahasiswa keperawatan, dan (3) dipublikasikan 10 tahun terakhir yaitu rentang tahun 20112020. Adapun kriteria eksklusi adalah artikel yang tidak tersedia dalam teks lengkap, artikel berganda dan artikel yang tidak cocok dengan pertanyaan penelitian. Setelah itu, dilakukan eksklusi yang tidak sesuai hasil penelitian. Seleksi Artikel teridentifikasi 80 artikel dari 5 database. Selanjutnya artikel dilakukan skrining oleh tiga orang peneliti. Pada artikel yang telah diidentifikasi, dieksklusi 6 artikel karena double publikasi, dilakukan ekslusi 18 artikel karena bukan full text. Kemudian, dilakukan eksklusi 44 artikel karena tidak sesuai dengan pertanyaan penelitian, dan dilakukan eksklusi 2 artikel karena bukan hasil penelitian. Ada 8 artikel yang diinklusi dalam penelitian ini yaitu artikel dengan penelitian intervensi, deskriptif, dan observasional (Gambar 1). Secara independen, author mengekstraksi data yang terkait judul, desain peneletian, sampel, tehnik sampling, tempat penelitian dan hasil penelitian. Setiap kutipan dinilai terhadap kriteria inklusi/eksklusi secara mandiri oleh satu author kemudian diperiksa oleh author lainnya, dan dideskripsikan pada tabel 1 .

\section{HASIL}

Berdasarkan hasil pencarian literatur dari 80 artikel yag didapatkan, terdapat 9 artikel yang memenuhi kriteria inklusi. Penelitian-penelitian tersebut mengidentifikasi prediktor apa saja yang mempengaruhi keberhasilan seseorang dalam melaksanakan Uji Kompetensi Ners Indonesia (UKNI). Hasil analisa artikel jurnal tersebut didapatkan bahwa ada beberapa prediktor yang mempengaruhi keberhasilan dalam menghadapi ujian kompetensi yaitu : prestasi akademik, hasil try out, bimbingan insentif, status akreditasi, indepent test taker berbasis web e-learning dan faktor demografi.

\section{Prestasi Akademik}

Prediktor pertama adalah prestasi akademik berdasarkan artikel yang ditulis oleh (Simon, McGinniss, and Krauss 2013; De Lima, London, and Manieri 2011; Hartina et al. 2017; Lukmanulhakim and Pusporini 2017; Rahadian et al. 2017; Abdillah 2016) menunjukkan bahwa prestasi akademik berhubungan dengan tingkat kelulusan UKNI. Semakin tinggi nilai prestasi akademik, semakin tinggi tingkat kelulusan dalam UKNI. 


\section{Hasil Try Out}

Prediktor kedua yaitu hasil try out, hasil penelitian yang ditulis oleh (Abdillah, 2016; De Lima et al., 2011; Hartina et al., 2017; Lukmanulhakim \& Pusporini, 2017) bahwa keikutsertaan Try Out UKNI berperan dalam kelulusan UKNI. Jika dilihat dari frekuensinya, responden yang mengikuti Try Out UKNI 1 kali peluang kelulusannya sebanyak $37,5 \%$, sementara itu, responden yang mengikuti $>1$ kali peluang kelulusannya sebanyak 69\%. Try Out merupakan suatu mekanisme yang digunakan sebagai sebuah latihan bagi seseorang sebelum melaksanakan ujian yang sesungguhnya. Try Out hanyalah sebagai media untuk berlatih mengerjakan soal. Semakin sering berlatih, peserta didik akan semakin siap untuk menghadapinya karena kesuksesan itu dimulai dari banyaknya latihan atau persiapan yang matang (Hartina et al., 2017). Try out merupakan salah satu cara untuk meningkatkan kemampuan mahasiswa dalam menghadapi uji kompetensi.

PubMed, Clinicalkey Nursing, Google Scholar Bahasa Inggris, Google Scholar Bahasa Indonesia dan Portal Garuda ( $\mathbf{n}: 80$ )

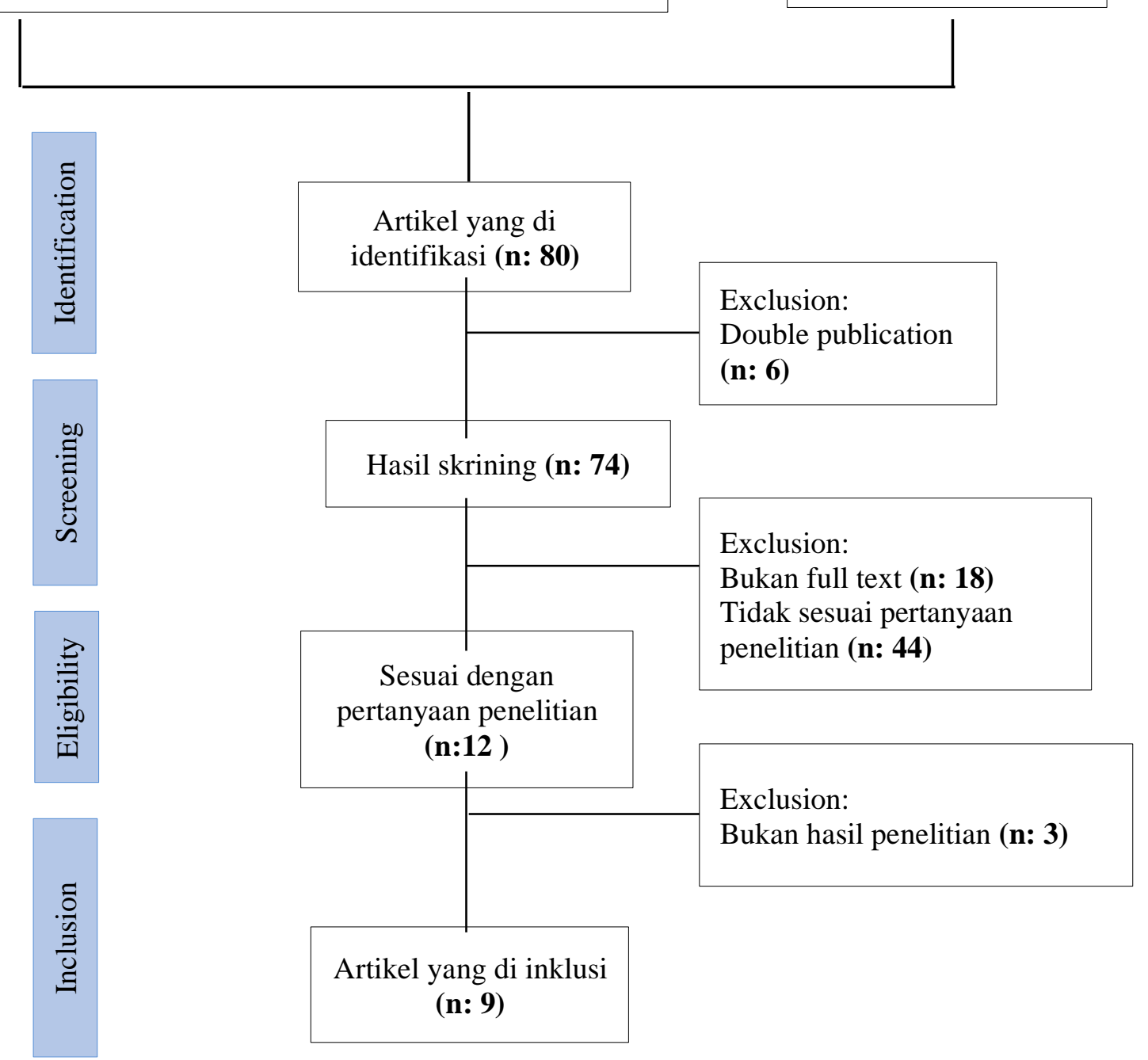

Gambar 1. Diagram alur untuk pemilihan dan Inklusi studi 
Tabel 1.

Deskripsi artikel penelitian

\begin{tabular}{|c|c|c|c|c|c|}
\hline $\begin{array}{c}\text { Author, Tahun } \\
\text { dan Negara }\end{array}$ & $\begin{array}{c}\text { Judul } \\
\text { Penelitian }\end{array}$ & $\begin{array}{l}\text { Desain } \\
\text { Penelitian }\end{array}$ & $\begin{array}{c}\text { Sampel dan } \\
\text { Tehnik } \\
\text { Sampling }\end{array}$ & $\begin{array}{c}\text { Tempat } \\
\text { Penelitian }\end{array}$ & Temuan Utama \\
\hline $\begin{array}{l}\text { Elizbeth B. } \\
\text { Simon } \\
\text { Shawn P. } \\
\text { Mcginniss } \\
\text { Batrice J. } \\
\text { Krauss } \\
(2013)\end{array}$ & $\begin{array}{l}\text { Prediktor } \\
\text { Variables for } \\
\text { NCLEX-RN } \\
\text { Readiness } \\
\text { Exam } \\
\text { Performance }\end{array}$ & $\begin{array}{l}\text { Penelitian } \\
\text { berjenis } \\
\text { kuantitatif } \\
\text { deskriptif } \\
\text { korelasi } \\
\text { dengan } \\
\text { pendekatan } \\
\text { cross } \\
\text { sectional } \\
\text { study }\end{array}$ & $\begin{array}{c}171 \\
\text { Responden }\end{array}$ & & $\begin{array}{l}\text { Prediktor } \\
\text { kesuksesan } \\
\text { NCLEX-RN: } \\
\text { - } \quad \text { GPA (IPK } \\
\quad \text { Akademik) } \\
\text { - } \quad \text { Usia } \\
-\quad \text { Ras }\end{array}$ \\
\hline $\begin{array}{l}\text { Michelle De } \\
\text { Lima, LaJune } \\
\text { London Ellen } \\
\text { Manieri }\end{array}$ & $\begin{array}{l}\text { Looking at the } \\
\text { past to change } \\
\text { the future: a } \\
\text { retrospective } \\
\text { study of } \\
\text { associate } \\
\text { degree in } \\
\text { nursing } \\
\text { graduates' } \\
\text { National } \\
\text { Council } \\
\text { Licensure } \\
\text { Examination } \\
\text { scores } \\
\end{array}$ & $\begin{array}{l}\text { Penelitian } \\
\text { berjenis } \\
\text { kuantitatif } \\
\text { dengan } \\
\text { pendekatan } \\
\text { Retrospektif } \\
\text { study }\end{array}$ & $\begin{array}{c}38 \\
\text { Responden }\end{array}$ & & $\begin{array}{l}\text { Prediktor } \\
\text { kesuksesan } \\
\text { NCLEX-RN: } \\
\text { Karakteristik } \\
\text { Demografi } \\
\text { - Jenis Kelamin } \\
\text { - Ras } \\
\text { Akademik } \\
\text { - IPK kumulatif } \\
\text { - } \quad \text { Ujian Health } \\
\quad \text { Education } \\
\quad \text { Systems } \\
\text { Incorporated } \\
\text { (HESI) }\end{array}$ \\
\hline $\begin{array}{l}\text { Ayu Hartina, } \\
\text { Takdir Tahir, } \\
\text { Nurhaya } \\
\text { Nurdin, } \\
\text { Midawati } \\
\text { Djafar (2018), } \\
\text { Indonesia }\end{array}$ & $\begin{array}{l}\text { Faktor Yang } \\
\text { Berhubungan } \\
\text { Dengan } \\
\text { Kelulusan Uji } \\
\text { Kompetensi } \\
\text { Ners Indonesia } \\
\text { (UKNI) Di } \\
\text { Regional } \\
\text { Sulawesi }\end{array}$ & $\begin{array}{l}\text { Penelitian } \\
\text { berjenis } \\
\text { kuantitatif } \\
\text { menggunakan } \\
\text { survey } \\
\text { analitik } \\
\text { dengan } \\
\text { pendekatan } \\
\text { cross } \\
\text { sectional } \\
\text { study }\end{array}$ & $\begin{array}{c}72 \\
\text { Responden } \\
\text { Cluster } \\
\text { Sampling }\end{array}$ & $\begin{array}{l}\text { Regional XII } \\
\text { Wilayah } \\
\text { Sulawesi }\end{array}$ & $\begin{array}{l}\text { Faktor yang } \\
\text { berhubungan } \\
\text { dengan } \\
\text { kelulusan } \\
\text { UKNI: } \\
\text { - Kesiapan } \\
\quad \text { Ujian } \\
\text { - } \text { Prestasi } \\
\quad \text { Akademik } \\
\text { - Peran } \\
\quad \text { Institusi } \\
\text { - Frekuensi } \\
\quad \text { keikutsertaan } \\
\quad \text { Try Out } \\
\text { Faktor yang } \\
\text { tidak } \\
\text { berhubungan } \\
\text { dengan } \\
\text { kelulusan } \\
\text { UKNI: }\end{array}$ \\
\hline
\end{tabular}




\begin{tabular}{|c|c|c|c|c|c|}
\hline $\begin{array}{l}\text { Author, Tahun } \\
\text { dan Negara }\end{array}$ & $\begin{array}{c}\text { Judul } \\
\text { Penelitian }\end{array}$ & $\begin{array}{c}\text { Desain } \\
\text { Penelitian }\end{array}$ & $\begin{array}{c}\text { Sampel dan } \\
\text { Tehnik } \\
\text { Sampling }\end{array}$ & $\begin{array}{c}\text { Tempat } \\
\text { Penelitian }\end{array}$ & Temuan Utama \\
\hline & & & & & $\begin{array}{ll}- & \text { Sistem } \\
& \text { Praktik } \\
& \text { Profesi } \\
- & \text { Kondisi } \\
& \text { Fisik }\end{array}$ \\
\hline $\begin{array}{l}\text { Lukmanulhakim } \\
\text { Lenny Stia } \\
\text { Pusporini } \\
\text { (2018), } \\
\text { Indoensia }\end{array}$ & $\begin{array}{l}\text { The Analysis } \\
\text { Of Factors } \\
\text { Influencing } \\
\text { Graduation } \\
\text { Achievement } \\
\text { In Nurse } \\
\text { Competence } \\
\text { Test Of Nurse } \\
\text { Profession } \\
\text { Program }\end{array}$ & $\begin{array}{l}\text { Penelitian } \\
\text { berjenis } \\
\text { kuantitatif } \\
\text { menggunakan } \\
\text { korelasi } \\
\text { analitik } \\
\text { dengan } \\
\text { pendekatan } \\
\text { cross } \\
\text { sectional } \\
\text { study }\end{array}$ & $\begin{array}{c}106 \\
\text { Responden } \\
\text { Total } \\
\text { Sampling }\end{array}$ & $\begin{array}{l}\text { Program } \\
\text { Studi Profesi } \\
\text { Ners STIKES } \\
\text { Falatehan } \\
\text { Serang }\end{array}$ & $\begin{array}{l}\text { Faktor yang } \\
\text { Mempengaruhi } \\
\text { capaian kelulusan } \\
\text { UKNI: } \\
\text { - IPK } \\
\quad \text { Akademik } \\
\text { - } \quad \text { Keaktifan } \\
\text { - } \quad \text { Hasil Try Out } \\
\quad \text { Nasional } \\
\text { Faktor yang } \\
\text { tidak } \\
\text { berhubungan } \\
\text { dengan } \\
\text { kelulusan } \\
\text { UKNI: } \\
\text { - Kecemasan } \\
\text { - Dukungan } \\
\text { Keluarga } \\
\text { - Dukungan } \\
\quad \text { Teman } \\
\quad \text { Sebaya }\end{array}$ \\
\hline $\begin{array}{l}\text { Deby } \\
\text { Zulkarnain } \\
\text { Rahardian Syah } \\
\text { Rahayu } \\
\text { Iskandar } \\
\text { Sujono Riyadi } \\
\text { (2017), } \\
\text { Indonesia }\end{array}$ & $\begin{array}{l}\text { Faktor-Faktor } \\
\text { Yang } \\
\text { Mempengaruhi } \\
\text { Kelulusan Uji } \\
\text { Kompetensi } \\
\text { Mahasiswa } \\
\text { Profesi Ners } \\
\text { Stikes Jenderal } \\
\text { Achmad Yani } \\
\text { Yogyakarta }\end{array}$ & $\begin{array}{l}\text { Penelitian } \\
\text { berjenis } \\
\text { kuantitatif } \\
\text { deskriptif } \\
\text { korelasi } \\
\text { dengan } \\
\text { pendekatan } \\
\text { cross } \\
\text { sectional } \\
\text { study }\end{array}$ & $\begin{array}{c}30 \\
\text { Responden } \\
\text { Simpel } \\
\text { Random } \\
\text { Sampling }\end{array}$ & $\begin{array}{l}\text { Stikes } \\
\text { Jenderal } \\
\text { Achmad } \\
\text { Yani } \\
\text { Yogyakarta }\end{array}$ & $\begin{array}{l}\text { Faktor yang } \\
\text { mempengaruhi } \\
\text { kelulusan UKNI } \\
\text { - IPK } \\
\text { Akademik S1 } \\
\text { \& Ners } \\
\text { - } \quad \text { Sarana } \\
\text { Prasarana } \\
\text { Akademik } \\
\text { Faktor yang tidak } \\
\text { berhubungan } \\
\text { - Lingkungan } \\
\text { - Praktek Ners } \\
\text { - Kecemasan } \\
\text { - Tingkat } \\
\quad \text { Spiritual } \\
\text { - Kepribadian } \\
\text { - Jenis Kelamin } \\
\text { - Program } \\
\quad \text { Peminatan }\end{array}$ \\
\hline $\begin{array}{l}\text { Alvin Abdillah } \\
(2016), \\
\text { Indonesia }\end{array}$ & $\begin{array}{l}\text { Analisis faktor } \\
\text { yang } \\
\text { mempengaruhi } \\
\text { Kelulusan Uji }\end{array}$ & $\begin{array}{l}\text { Penelitian } \\
\text { berjenis } \\
\text { kuantitatif } \\
\text { dengan }\end{array}$ & $\begin{array}{c}145 \\
\text { Responden }\end{array}$ & $\begin{array}{l}\text { STIKes } \\
\text { Ngudia } \\
\text { Husad a } \\
\text { Madura }\end{array}$ & $\begin{array}{l}\text { Faktor yang } \\
\text { mempengaruhi } \\
\text { kelulusan UKNI } \\
\text { - IPK }\end{array}$ \\
\hline
\end{tabular}




\begin{tabular}{|c|c|c|c|c|c|}
\hline $\begin{array}{l}\text { Author, Tahun } \\
\text { dan Negara }\end{array}$ & $\begin{array}{c}\text { Judul } \\
\text { Penelitian }\end{array}$ & $\begin{array}{c}\text { Desain } \\
\text { Penelitian }\end{array}$ & $\begin{array}{c}\text { Sampel dan } \\
\text { Tehnik } \\
\text { Sampling }\end{array}$ & $\begin{array}{c}\text { Tempat } \\
\text { Penelitian }\end{array}$ & Temuan Utama \\
\hline & $\begin{array}{l}\text { Kompetesi } \\
\text { Ners Indonesia }\end{array}$ & $\begin{array}{l}\text { pendekatan } \\
\text { cross sectional } \\
\text { study }\end{array}$ & $\begin{array}{c}\text { Simpel } \\
\text { Random } \\
\text { Sampling }\end{array}$ & & $\begin{array}{l}\text { - Gaya Belajar } \\
\text { - } \quad \text { Try Out }\end{array}$ \\
\hline $\begin{array}{l}\text { Rachmat } \\
\text { Chusnul } \\
\text { Choeron, } \\
\text { Wahyu Dini } \\
\text { Metrikayanto } \\
(2020), \\
\text { Indonesia }\end{array}$ & $\begin{array}{l}\text { Meningkatkan } \\
\text { Kesiapan Uji } \\
\text { Kompetensi } \\
\text { Ners Melalui } \\
\text { bimbingan } \\
\text { insentif }\end{array}$ & $\begin{array}{l}\text { Penelitian ini } \\
\text { adalah } \\
\text { penelitian } \\
\text { eksprimen } \\
\text { one group } \\
\text { pre-post test } \\
\text { design }\end{array}$ & $\begin{array}{c}60 \\
\text { Responden } \\
\text { Tehnik } \\
\text { Random } \\
\text { Sampling }\end{array}$ & $\begin{array}{l}\text { Fakultas } \\
\text { Ilmu } \\
\text { Kesehatan } \\
\text { Universitas } \\
\text { Tribhuwana } \\
\text { Tunggadewi } \\
\text { Malang }\end{array}$ & $\begin{array}{l}\text { Bimbingan } \\
\text { Insentif }\end{array}$ \\
\hline $\begin{array}{l}\text { Teuku Tahlil } \\
\text { Darmawati, } \\
\text { Nurhasannah, } \\
\text { Maulina (2019), } \\
\text { Indonesia }\end{array}$ & $\begin{array}{l}\text { Metode } \\
\text { Independent } \\
\text { Test Taker } \\
\text { Dalam Upaya } \\
\text { Peningkatan } \\
\text { Lulusan Uji } \\
\text { Kompetensi } \\
\text { Ners }\end{array}$ & $\begin{array}{l}\text { Penelitian ini } \\
\text { adalah } \\
\text { penelitian } \\
\text { eksprimen, } \\
\text { dengan pre- } \\
\text { test dan post- } \\
\text { test design }\end{array}$ & $\begin{array}{c}22 \\
\text { Responden } \\
\text { Simpel } \\
\text { Random } \\
\text { Sampling }\end{array}$ & $\begin{array}{l}\text { Fakutas } \\
\text { Keperawatan } \\
\text { Universitas } \\
\text { Syiah Kuala, } \\
\text { Banda Aceh }\end{array}$ & $\begin{array}{l}\text { Indepent test } \\
\text { taker berbasis } \\
\text { web e-learnig }\end{array}$ \\
\hline Masfuri & $\begin{array}{l}\text { Uji } \\
\text { Kompetensi } \\
\text { Perawat di } \\
\text { Indonesia }\end{array}$ & $\begin{array}{l}\text { Penelitian ini } \\
\text { menggunakan } \\
\text { data sekunder } \\
\text { yang telah } \\
\text { diterbitkan } \\
\text { oleh panitia } \\
\text { uji } \\
\text { kompetensi } \\
\text { nasional. }\end{array}$ & $\begin{array}{c}\text { Data secara } \\
\text { keseluruhan } \\
\text { yang } \\
\text { mengikuti } \\
\text { ujian tahun } \\
2015 \\
\text { adalah } \\
66.687 \\
\text { peserta dari } \\
1.179 \\
\text { institusi } \\
\text { pendidikan } \\
\text { keperawatan }\end{array}$ & Indonesia & Status Akreditasi \\
\hline
\end{tabular}

\section{Bimbingan insentif}

Prediktor ketiga yaitu bimbingan insentif penelitian Choeron and Metrikayanto (2020), bahwa kesiapan mahasiswa dalam menghadapi uji kompetensi ners sebelum diberikan bimbingan intensif berada pada rerata 36,00 dan kesiapan mahasiswa dalam menghadapi uji kompetensi ners setelah diberikan bimbingan intensif berada pada rerata 45,89. Selain itu, hasil penelitian ini juga membuktikan bahwa bimbingan intensif efektif meningkatkan kesiapan mahasiswa dalam menghadapi uji kompetensi ners. Bimbingan belajar intensif telah terbukti meningkatkan kesiapan mahasiswa dalam menghadapi uji kompetensi nasional, walaupun dalam proses akademiknya mahasiswa telah diarahkan pada pemecahan kasus (Syapitri \& Hutajulu, 2020).

\section{Status Akreditasi}

Prediktor keempat yaitu status akreditasi penelitian Masfuri, (2017) menunjukkan pengaruh yang baik bagi tingkat kelulusan. Jika dilihat dari status akreditasi program studi dengan akreditasi A memiliki kelulusan yang stabil dan lebih tinggi dibandingkan dengan program studi akreditasi B dan C. Hal ini sesuai dengan tingkatan akreditasi yang lebih tinggi 
memiliki kecenderungan tingkat kelulusan yang lebih baik (Masfuri, 2017).

\section{Indepent test taker berbasis web e- learning}

Prediktor kelima yaitu indepent test taker berbasis web e-learning menunjukkan bahwa ada pengaruh yang signifikan dari program independent test taker menggunakan web e-learning terhadap peningkatan nilai rata-rata peserta ujian ( $p$ value $=0.000$ ). Metode multimedia terlihat cocok untuk menunjang pembelajaran dalam menghadapi Uji Kompetensi Ners Indonesia (UKNI) adalah menggunakan metode independent test taker. Metode ini didasari dengan penggunaan perangkat lunak berupa web e-learning yang akan memfasilitasi mahasiswa untuk mendapatkan suatu materi dan mempelajarinya pada perangkat komputer masing-masing (Tahlil et al., 2019)

\section{Faktor Demografi}

Prediktor keenam yaitu faktor demografi yaitu jenis kelamin, ras dan usia. Penelitian De Lima et al., (2011) yang melakukan penelitian di USA dengan analisis data demografi mengungkapkan bahwa wanita memiliki tingkat lulus sedikit lebih tinggi pada 54\% dibandingkan dengan laki-laki dengan persentasi $42 \%$. siswa putih memiliki tingkat lulus tertinggi pada $58 \%$ diikuti oleh siswa Hitam di $44 \%$.

\section{PEMBAHASAN}

Tinjauan literatur ini bertujuan untuk mengidentifikasi prediktor ujian kompetensi ners. Dari 9 artikel yang ditinjau yaitu 2 penelitian eksperimen 5 penelitian cross sectional study dan 2 penelitian retrospektif study. Berdasarkan hasil analisis, prediktor ujian kompetensi ners, ada 6 prediktor yang menjadi temuan dalam penelusurun.

Prediktor pertama yang menjadi prestasi akademik, hal ini terjadi karena pada program pendidikan akademik dan UKNI yang cenderung terpusat pada ranah kognitif. Mahasiswa yang memiliki indeks prestasi kumulatif (IPK) yang baik pada tahap akademik akan lebih mudah memahami konsep ataupun teori-teori yang telah didapatkan pada saat menempuh pendidikan dan akan lebih mudah mengingat serta kemampuan analisisnya lebih meningkat sehingga mahasiswa tersebut akan mudah mengerjakan soal ujian dan hasil yang didapat juga akan memuaskan (Khasanah et al., 2017). Predikat kelulusan untuk program profesi ners ditentukan dengan hasil nilai IPK. Dimana predikat IPK merupakan gambaran dari keberhasilan akan prestasi belajar. Kategori predikat IPK pada program Profesi Ners terbagi diantaranya; cumlaude, sangat memuaskan dan memuaskan. Prestasi akademik memiliki hubungan yang erat dalam menentukan kelulusan hasil review artikel menyatakan bahwa IPK akademik memiliki hubungan yang erat dengan kelulusan uji kompetensi. Semakin tinggi IPK peserta ujian kompetensi maka kecenderungan untuk lulus dalam ujian kompetensi akan semakin baik (Abdillah, 2016; Lukmanulhakim \& Pusporini, 2017; Syah et al., 2017).

Try Out merupakan salah satu yang menjadi prediktor keberhasilan peserta dalam menghadapi ujian kompetensi, try out merupakan salah satu cara untuk meningkatkan kemampuan mahasiswa dalam menghadapi uji kompetensi, mahasiswa yang mengikuti try out akan lebih siap mengerjakan soal ujian karena telah memiliki gambaran model soal yang akan keluar dan pada saat ujian kompetensi dilaksanakan peserta akan lebih siap (Abdillah, 2016; Lukmanulhakim \& Pusporini, 2017). Try out juga merupakan suatu alat yang dapat digunakan untuk mengukur kemampuan seseorang sebelum melaksanakan ujian yang sesungguhnya dan try out sebagai media untuk berlatih mengerjakan soal. semakin sering seseorang berlatih, maka peserta ujian akan semakin siap untuk menghadapi UKNI karena keberhasilan itu dimulai dari persiapan yang matang dan banyaknya latihan (Hartina et al., 2017). Namun, try out berbeda dengan bimbingan intensif, karena dalam try out mahasiswa hanya 
dilatih untuk mengerjakan soal-soal, tidak diajarkan bagaimana cara memecahkan soal. Bimbingan intensif penting diberikan oleh institusi kepada mahasiswa sebelum pelaksanaan uji kompetensi nasional. Melalui bimbingan intensif mahasiswa tidak hanya diajarkan bagaimana cara memecahkan kasus-kasus yang ada dalam soal, tetapi juga bagaimana menemukan dan menerapkan pola penyelesaian masalah dari masing-masing departemen yang diujikan. Pola-pola pemecahan masalah merupakan hal terpenting yang harus dikuasai oleh mahasiswa, karena setiap departemen yang diujikan memiliki pola yang berbeda-beda (Choeron \& Metrikayanto, 2020).

Prediktor lain yang perlu diperhatikan suatu institusi pendidikan adalah akreditasi merupakan suatu kegiatan penilaian untuk menentukan kelayakan program studi dan perguruan tinggi (Kemenristekdikti, 2016). Akredirasi yang unggul dan baik dalam sebuah institusi pendidikan akan cenderung memiliki potensi kelulusan yang tinggi dalam uji kompetensi ners.

Hal lain yang dapat menjadi prediktor uji kompetensi yaitu Independent test taker adalah suatu metode yang menggunakan multimedia untuk menunjang pembelajaran mahasiswa menghadapi UKNI. Metode ini didasari asumsi bahwa penggunaan web $e$ learning akan memfasilitasi mahasiswa untuk mendapatkan suatu materi dan mempelajarinya pada perangkat masingmasing. Penggunaan metode web e-learning dapat membantu mahasiswa dalam mencapai kelulusan, seringnya mahasiswa terpapar dengan soal-soal berkaitan dengan kasus akan memudahkan dalam memecahkan soa-soal pada saat mengikuti ujian kompetensi (Tahlil et al., 2019)

\section{KESIMPULAN}

Uji kompetensi nasional telah diterapkan sejak tahun 2013 yang merupakan standar kompetensi bagi perawat di Indonesia. Tingkat kelulusan yang belum merata dapat menjadi perhatian buat institusi pendidikan. Salah satu jalan yang dapat dipertimbangkan dengan melakukan persiapan dengan mengidentifikasi faktor prediktor kelulusan ujian kompetensi dalam suatu institusi pendidikan sehingga berguna dalam membuat strategi/intervensi meningkatkan kelulusan ujian kompetensi ners.

\section{DAFTAR PUSTAKA}

Abdillah, A. (2016). Analisis Faktor-Faktor yang Mempengaruhi Kelulusan Uji Kompetensi Ners Indonesia. JPAP: Jurnal Penelitian Administrasi Publik, 2(2), 373-380. https://doi.org/10.30996/jpap.v2i02.9 96

Benefiel, D. (2011). The story of nurse licensure. Nurse Educator, Lippincott Williams \& Wilkins, 36(1), 16-20. https://doi.org/10.1097/NNE.0b013e3 $182001 \mathrm{e} 82$

Choeron, R. C., \& Metrikayanto, W. D. (2020). Meningkatkan Kesiapan Uji Kompetensi Ners Melalui Bimbingan Intensif. In Jurnal Ilmiah Keperawatan (Scientific Journal of Nursing) (Vol. 6, Issue 1, pp. 143147).

https://doi.org/10.33023/jikep.v6i1.57 4

De Lima, M., London, L., \& Manieri, E. (2011). Looking at the past to change the future: a retrospective study of associate degree in nursing graduates' National Council Licensure Examination scores. Teaching and Learning in Nursing, 6(3), 119-123. https://doi.org/10.1016/j.teln.2011.01. 001

Hartina, A., Tahir, T., Nurdin, N., \& Djafar, M. (2017). Faktor Yang Berhubungan Dengan Kelulusan Uji Kompetensi Ners Indonesia (UKNI) Di Regional Sulawesi. Jurnal Persatuan Perawat Nasional Indonesia (JPPNI). https://doi.org/10.32419/jppni.v2i2.84

Kariasa, I. M., Tahir, T., Rahayu, U., Santoso, A., Slametiningsih, Soesanto, E., Probowati, R., \& Wahyuni, S. (2018). SiNERSI Hadirkan Sukses Uji Kompetensi Ners Indonesia (I. M. Kariasa (ed.)). Asosiasi Institusi Pendidikan Ners Indonesia (AIPNI).

Kemenristekdikti. (2016). Peraturan 
Menteri Riset, Teknologi, dan Pendidikan Tinggi Republik Indonesia (p. 32). Kementerian Riset,Teknologi dan Pendidikan Tinggi.

Khasanah, U., Sudiyanto, H., A, F. W., \& Fatmawati, A. (2017). Analisis Faktor - Faktor Yang Berhubungan Dengan Tingkat Kelulusan Uji Kompetensi Mahasiswa S1 Keperawatan di STIKES Majapahit Mojokerto. Medica Majapahit, 9(2), 182-192. http://103.38.103.27/lppm/index.php/ $\mathrm{MM} /$ article/view/201

Kholifah, K., Kholifah, S., \& Kusumawati, W. (2016). Hambatan Lulusan Ners Dalam Menghadapi Uji Kompetensi Ners Indonesia. The Indonesian Journal of Health Sciencehe, 7(1), 8. https://doi.org/10.32528/the.v7i1.383

Lukmanulhakim, \& Pusporini, L. S. (2017).

The Analysis Of Factors Influencing Graduation Achievement In Nurse Competence Test Of Nurse Profession Program. In Cakrawala Pendidikan (Vol. 37, Issue 2, pp. 306-320). https://doi.org/10.21831/cp.v37i2.198 81

Masfuri. (2017). Uji Kompetensi Perawat Di Indonesia. Jurnal Persatuan Perawat Nasional Indonesia (JPPNI), 1(1), 87. https://doi.org/10.32419/jppni.v1i1.17 Republik Indonesia. (2014). Undang Undang Republik Indonesia Nomor 38 Tahun 2014 Tentang Keperawatan. Sekretariat Negara Jakarta.

Ristek Dikti. (2020). Registrasi Online Uji Kompetensi NERS. http://ukners.ristekdikti.go.id/pages/st atistik_lulus

RistekDikti. (2014). Registrasi Online Uji Kompetensi NERS. RistekDikti.

Simon, E. B., McGinniss, S. P., \& Krauss, B. J. (2013). Predictor variables for NCLEX-RN readiness exam performance. Nursing Education Perspectives, 34(1), 18-24. https://doi.org/10.5480/1536-502634.1.18

Syah, D. Z. R., Iskandar, R., \& Riyadi, S. (2017). Faktor-Faktor Yang Mempengaruhi Kelulusan Uji
Kompetensi Mahasiswa Profesi Ners Stikes Jenderal Achmad Yani Yogyakarta. Jurnal Wacana Kesehatan, 2(2), 180-190. https://doaj.org/article/28799bb96897 439081fad6dc35a6dedc

Syapitri, H., \& Hutajulu, J. (2020). Strategi Mahasiswa Profesi Ners Dalam Menghadapi Uji Kompetensi Ners di USM Indonesia. Jurnal Surya Muda, 2(2), 76-84. https://doi.org/10.38102/jsm.v2i2.66

Tahlil, T., Darmawati, Nurhasannah, \& Maulina. (2019). Metode Independent Test Taker Dalam Upaya Peningkatan Lulusan Uji Kompetensi Ners. Idea Nursing Journal, 10(1), 15-20. http://erepository.unsyiah.ac.id/INJ/article/vi ew/16548 